\title{
Community-Based Health Education Improve Knowledge and Attitudes of COVID-19 Prevention
}

\author{
Emdat Suprayitno*, Syaifurrahman Hidayat, Dian Permatasari, Elyk Dwi \\ Mumpuningtias, Yulia Wardita \\ Universitas Wiraraja, Indonesia \\ Corresponding author: emdat@wiraraja.ac.id
}

\begin{abstract}
Background: Corona Virus Disease-19 is becoming a pandemic. The easy-to-spread nature of the virus which requires good knowledge and good attitude in determining preventive measures to break Covid-19 transmission.

Purpose: This study aimed to determine the effect of community-based health education on knowledge and attitudes of Covid-19 prevention.

Methods: This is quantitative research with design of quasi-experimental. The sampling technique used was simple random sampling, the samples were 62 people divided into two groups. The intervention group that received the intervention of community-based health education and control group that received a Covid-19 leaflet.

Results: The research result found that Mann Whitney U test score of knowledge between intervention and control group after the given intervention was $p=0.004$. Independent $T$ test score of attitudes between intervention and control group after intervention was $p=0.003$. The Mann Whitney U test score of knowledge differences $(\Delta)$ between intervention group and the control group after intervention was $p=0.002$. Mann Whitney $U$ test of attitudes differences $(\Delta)$ between intervention group and the control group after intervention was $\mathrm{p}=0.000$.
\end{abstract}

Conclusion: The research showed that respondents in the intervention group have better knowledge and better attitudes. The community-based health education method can be an alternative option to promote and prevent the spread of Covid-19 infection.

Keywords: Health Education, Knowledge, Attitudes, Covid-19. 
Journal Of Nursing Practice

http://thejnp.org

ISSN: 2614-3488 (print); 2614-3496 (online)

Vol.5 No.1. October 2021. Page.136-145

\section{BACKGROUND}

Covid-19 is currently a serious world problem whereas the number of cases is keeps on increasing each day. The virus is infecting everyone regardless the age or gender. Covid19 first originated in the Wuhan city in Hubei Province, China in December 2019. Since then it has spread in over 210 countries and areas (Sohrabi et al., 2020). This is a virus disease that caused by a virus of Severe Acute Respiratory Syndrome Coronavirus (SARSCoV-2). Since the first infection of Coronavirus disease 2019 (Covid-19) happened in the Wuhan, China, the infection is spreading fast across the world and becoming pandemic and global crisis (Cucinotta \& Vanelli, 2020). The cumulative number of Covid-19 total cases across the world is increasing exponentially.

On the $3^{\text {rd }}$ April 2020, there were almost a million cases of confirmed Covid-19 across the globe, including 80,000 in China. Covid-19 which caused by SARS-CoV2 is a respiratory disease that highly contagious, especially transmitted from droplet and direct contact (Surgery et al., 2020). The phenomenon in the ground that was observed by researchers was there were many people in the Murtajih village, such as in the market and other public spaces who did not exercise prevention measure by wearing mask. Additional finding was proper handwash using soap was rarely observed. The result of prior study by Jaji (2020), shown that there is difference between the score of knowledge about Covid-19 prevention after given intervention of health education (Jaji, 2020). The purpose of this research is to provide innovation of community-based health education on the knowledge and attitudes of Covid-19 prevention.

A person that diagnosed positive Covid-19 shown a symptom of flu with dry cough, throat ache, high fever, and other respiratory problem. Around 2.2 million people had been infected and more than 0.15 million people were dead death globally. USA is a country that affected the most with the number of patient's infected around 0.7 million. Although the measure taken was high, there is no cure for this disease. However, prevention and management is the best option (Ali \& Alharbi, 2020). In Madura, the first positive case of covid-19 occurred in Pamekasan Regency on March 30, 2020 with an additional one patient under monitoring and 128 people under monitoring, while in other districts in Madura, namely Bangkalan there is one patient under monitoring, and 196 people under monitoring. Sampang Regency has 87 people under monitoring and Sumenep Regency has 65 people under monitoring (Sakti, 2020). Since Pamekasan Regency is declared as red zone, it has caused some people to become worried and anxious. Based on interviews with 6 Pamekasan residents in Pademawu Village, they said that they still did not understand the protocol of transmission prevention and how Covid-19 is transmitted

The causes of Covid-19 transmission are many factors, but research says one of them is the lack of public knowledge about Covid-19 and its prevention. Covid-19 can infect and be contagious if a person touches a surface contaminated with SARS-CoV-2 and then comes into direct contact with mucous membranes such as the eyes, nose or mouth (Lotfi et al., 2020). It has been reported that the virus capable of infect human in the range of six foot (1.8 metres). The virus able to survive for two hours until a couple of days in the droplet from cough or sneeze that land in the ground. The infection can happen by touching things or surfaces that have been infected by the virus, even though this is not the main path of infection (Jaimes et al., 2020). The common symptoms of infection are restlessness, muscle pain, sneeze, throat ache, dry cough, high fever, respiratory disorders, etc. The severe cases developing pneumonia, severe respiratory syndrome, kidney failure, and even death (Huang et al., 2020). The transmission of human to human contributed greatly to the infection pandemic. The Covid-19 infection transmitted by droplet, cough, contaminated hands/ surface. However the transmission prevention of human to human can be reduced by 


\section{Journal Of Nursing Practice}

http://thejnp.org

ISSN: 2614-3488 (print); 2614-3496 (online)

Vol.5 No.1. October 2021. Page.136-145

frequent handwash with soap and water or disinfecting the hands using alcohol based cleaners as recommended by WHO (Pradhan et al., 2020)

Preventive action is the key to implementation in health and community services. Measures for prevention in the community are maintaining hand hygiene, using hand sanitizers or washing hands with soap and running water, avoiding touching parts of the face (such as eyes, nose and mouth), applying coughing and sneezing ethics, wearing masks and keeping a distance at least 1 meter) from other people (Jaji, 2020). Theoretically, the component of public behavior in Covid-19 prevention action consist of knowledge, attitudes, and action. To render a habit into a behavior, starting from knowledge and attitudes should be good towards something that will become a behavior change (Notoatmodjo, 2010). Knowledge one of which received from health workers and health cadre by using various method and media such as community-based health education (Suprayitno, Purnomo, et al., 2020).

Prevention and treatment are paramount to control Covid-19. Therefore, collective efforts of the community and government are urgently needed (Suprayitno, Rahmawati, et al., 2020). The recommendation to minimize infection is to avoid sneezing and coughing in public, handwash using soap, cover mouth and nose with a mask when sneezing and coughing (Jin et al., 2020). It is also advisable to stay at home if anyone has flu symptoms. It is also best not to go to school, work and public places, not to use public transportation (plane, train, metro, bus, taxi, etc.) (Ali \& Alharbi, 2020). In the current pandemic, people must follow health care instructions and avoid close contact with other people, especially individuals with compromised immune systems. Also, frequent hand washing and following strict personal hygiene measures are necessary to control transmission of the virus. (Alahdal et al., 2020).

\section{OBJECTIVE}

The research purpose is to determine the effect of community-based health education on knowledge and attitudes of Covid-19 prevention.

\section{METHODS}

This research was a quantitative research with a quasi-experimental design. The population in this study was the people in the East Solo hamlet and North Solo, Murtajih Village, Pademawu sub-district. The sampling technique used was simple random sampling, the samples were 62 people divided into 2 groups, namely the control group and intervention group. The intervention group was given community-based health education intervention. The first health education was carried out by researchers by visiting each respondent's house with the Pademawu Village nurses. The materials were the Covid-19 definitions, Covid-19 modes of transmission, the procedure of wearing masks and handwash with the correct soap using poster as the media. On the second day, the health education continued at the house of the chief of the East Solo hamlet by exercised Health protocol, namely measuring body temperature, washing hands with soap, wearing masks and doing physical distancing for each person by 1.5 meters away. Health education was carried out by Health cadres involving the chief of Murtajih Village and with researchers by delivering the same material as on the first day. Meanwhile the control group was only given leaflets about the prevention of Covid-19 to each respondent's house. The results of the study were analyzed using the wilcoxeon test, Mann Whitney $\mathrm{U}$ test and the Independent $t$ test. 


\section{Journal Of Nursing Practice}

http://thejnp.org

ISSN: 2614-3488 (print); 2614-3496 (online)

Vol.5 No.1. October 2021. Page.136-145

RESULTS

General Data

Table 1 The respondent's distribution according to age

\begin{tabular}{ccc}
\hline Age & Total & Percentage \\
\hline 26-35 Years & 3 & 4,8 \\
36-45 Years & 38 & 61,3 \\
$46-55$ Years & 4 & 6,5 \\
$56-65$ Years & 13 & 21 \\
$>65$ Years & 4 & 6,5 \\
\hline Total & 62 & 100
\end{tabular}

Table 1 shown that the age of respondents were majority $36-45$ years as much as 38 people $(61,3 \%)$.

Table 2 The respondent's distribution according to education

\begin{tabular}{ccc}
\hline Education & Total & Percentage \\
\hline Unfinish elementary & 5 & 8,1 \\
Elementary & 10 & 16,1 \\
Junior high & 14 & 22,6 \\
Senior high & 21 & 33,9 \\
Higher education & 12 & 19,4 \\
\hline Total & 62 & 100
\end{tabular}

Table 2 shown the education of respondents were majority Senior high as much as 21 people $(33,9 \%)$.

Table 3 The respondent's distribution according to gender

\begin{tabular}{ccc}
\hline Gender & Total & Percentage \\
\hline Male & 28 & 45,2 \\
Female & 34 & 54,8 \\
\hline Total & 62 & 100 \\
\hline
\end{tabular}

Table 3 shown the gender of respondents were majority male as much as 34 people $(54,8 \%)$.

Table 4 The respondent's distribution according to occupation

\begin{tabular}{ccc}
\hline Occupation & Total & Percentage \\
\hline Civil servant & 4 & 6,5 \\
Farmer & 27 & 43,5 \\
Entrepreneur & 7 & 11,3 \\
Private employer & 24 & 38,7 \\
\hline Total & 62 & 100
\end{tabular}

Table 4 shown the occupation of respondents were majority farmer as much as 27 people $(43,5 \%)$.

\section{Specific Data}

2.1. The comparison between mean score of public knowledge and attitudes to wearing mask and hand washing in the prevention of Covid-19 in the control group

\begin{tabular}{ccccc}
\hline Variable & Score & Mean & SD & P value \\
\hline \multirow{2}{*}{ Knowledge } & Pre & 9,06 & 1,03 & \multirow{2}{*}{0,046} \\
& Post & 9,19 & 1,01 & \\
\hline
\end{tabular}




\begin{tabular}{lllll}
\cline { 2 - 2 } Attitude & Pre & 30,67 & 3,20 & 0 \\
& Post & 30,83 & 3,14 & \\
\hline
\end{tabular}

Based on table 2.1, the mean of the knowledge score of the control group before health education was $9.06 \pm 1.03$ and the mean of the knowledge after health education was $9.19 \pm 1.01$. The Wilcoxon test result of knowledge score was $p=0.046$, means that there is no significant difference in the knowledge score in the community-based health education group. While the mean of the attitudes score of the control group before health education was $30.67 \pm 3.20$ and the average attitude score after health education was $30.83 \pm 3.14$. The paired $t$ test result of attitudes score was $p=0.096$, means that there is no significant difference in attitude scores in the control group before and after community-based health education.

The comparison between mean score public knowledge and attitudes to wearing mask and hand washing in the prevention of Covid-19 in the intervention and control group before community-based health education treatment.

\begin{tabular}{ccccc}
\hline Variable & Group & Mean & SD & P value \\
\hline \multirow{2}{*}{ Knowledge } & Intervention & 9,32 & 1,13 & \multirow{2}{*}{0,343} \\
& Control & 9,06 & 1,03 & \\
\hline \multirow{2}{*}{ Attitude } & Intervention & 31,25 & 3,58 & \multirow{2}{*}{0,927} \\
\cline { 2 - 4 } & Control & 30,67 & 3,20 & \\
\hline
\end{tabular}

Based on table 2.2, the mean of the knowledge score of the intervention group before community-based health education was $9.32 \pm 1.13$ and the control group was $9.06 \pm 1.03$. The results of the Mann Whitney test of knowledge score was $p=0.343$, means that there is no significant difference in knowledge scores in the intervention group and the control group before community-based health education. Meanwhile, the mean of the attitudes score of the intervention group before community-based health education was $31.25 \pm 3.58$ and the control group was $30.67 \pm 3.20$. The results of the independent $t$ test of attitude score was $p$ $=0.927$, means that there is no significant difference in attitude's scores in the intervention group and the control group before community-based health education.

The comparison between mean score of public knowledge and attitudes to wearing mask and hand-washing in the prevention of Covid-19 in the intervention and control groups after community-based health education.

\begin{tabular}{ccccc}
\hline Variable & Group & Mean & SD & P value \\
\hline \multirow{2}{*}{ Knowledge } & Intervention & 9,93 & 0,85 & \multirow{2}{*}{0,004} \\
& Control & 9,19 & 1,01 & \\
\hline \multirow{2}{*}{ Attitude } & Intervention & 33,06 & 2,30 & \multirow{2}{*}{0,003} \\
& Control & 30,83 & 3,14 & \\
\hline
\end{tabular}

Based on table 2.4, the mean of the knowledge score of the intervention group after community-based health education was $9,93 \pm 0,85$ and the control group was $9,19 \pm 1,01$. The results of the Mann Whitney test of knowledge score was $p=0.004$, means that there is a significant difference in the knowledge score in the intervention group and the control group after community-based health education is carried out. Meanwhile the mean of the attitudes score of the intervention group after community-based health education was 33.06 $\pm 2,30$ and the control group was $30,83 \pm 3,14$. The independent $t$ test result of attitude score was $p=0.003$, means that there is a significant difference of attitudes score in the intervention group and the control group after community-based health education. 
The comparison between the difference $(\Delta)$ of the mean of public knowledge and attitudes, before and after community-based education in the intervention group and the control group.

\begin{tabular}{ccccc}
\hline Variable & Group & Mean & SD & P value \\
\hline \multirow{2}{*}{ Knowledge } & Intervention & 0,61 & 0,71 & \multirow{2}{*}{0,002} \\
& Control & 0,12 & 0,06 & \\
\hline \multirow{2}{*}{ Attitude } & Intervention & 1,80 & 2,31 & \multirow{2}{*}{0,000} \\
& Control & 0,16 & 0,52 & \\
\hline
\end{tabular}

Based on table 2.5, the difference $(\Delta)$ of the mean of knowledge in the treatment group before and after community-based health education was $0.61 \pm 0.71$ and the control group was $0.12 \pm 0.06$. The Mann Whitney test results of knowledge score was $p=0.002$, means that there is a significant difference in the $\Delta$ of the mean of knowledge scores in the intervention group and the control group after community-based health education. Meanwhile the difference $(\Delta)$ of the mean score of attitude score of the intervention group before and after community-based health education was $1.80 \pm 2.31$ and the control group was $0.16 \pm 0.52$. The Mann Whitney test result of attitude score was $p=0.000$, means that there is a significant difference in the $\Delta$ of the mean of attitude scores in the intervention group and the control group after community-based health education

\section{DISCUSSION}

\section{The effect of community-based health education on covid-19 prevention knowledge}

Based on the results of the study, there were differences in knowledge scores in the control group and the intervention group which indicated that community-based health education interventions were effective in increasing knowledge of Covid-19 prevention. The results of this study are in line with research which states that community-based education provided by the community for the community itself can increase knowledge (Zeinomar \& Moslehi, 2013). The research results of Jaji (2020) shows that there are differences in the score of knowledge about the prevention of the covid-19 virus after the Health Education intervention (Jaji, 2020). Analytical surveillance results from the WHO report show that improving hand hygiene practices can reduce the transmission of pathogens in healthcare by $50 \%$ (Surgery et al., 2020). Several studies shown that the use of face masks by the general public has the potential to be of high value in limiting the transmission of Covid-19 (Eikenberry et al., 2020). Increased knowledge can occur due to interactions with other people and the social environment, making it possible through these interactions to gain understanding. The level of knowledge is divided into two, namely good and bad (Prihanta et al., 2016). Good and bad knowledge gives meaning to an assessment of one's obedience behavior (Priyanto, 2018). In the implementation of community-based health education interventions carried out by researchers accompanied by nurses, village chiefs and health cadres, this can affect the acceptance of respondents' knowledge. Community as Partner by Anderson \& McFarlane (2000) is a development of Betty Newman model, focusing to community as partner and nursing process as an approach. This model emphasizing public active participation to improve and prevent health problem. Naturally, individual will form group in the community which slowly affect the community health in general (Munir 2015). Employed group as a target is the best moves in providing health education to them who have similar background (Huriah, 2007).

The results showed that Health Education could increase one's knowledge. The success of health education can also be supported by the existence of tools or media to help facilitate the delivery of messages or material to be conveyed. One of the health education media used by researchers is the poster media. Posters are visual media used to convey 


\section{Journal Of Nursing Practice}

http://thejnp.org

ISSN: 2614-3488 (print); 2614-3496 (online)

Vol.5 No.1. October 2021. Page.136-145

messages or materials through pictures, colors and writing (Ulya et al., 2018). This can increase the reader's interest in reading the information contained therein. Some respondents said that they were interested in reading posters because they were accompanied by colors and images, so they were curious and read them repeatedly. In addition, its simple form and easy to paste anywhere makes it easier for readers to read the poster without having to search for it first (Daryanto, 2015), (Ulya et al., 2018). Poster is a medium that presents information in visual form and stimulates the sense of sight. Most of human knowledge is obtained through the sense of sight and information is more often remembered if they can read the information independently. The use of poster media aims to present information in an attractive form, easy to understand, and can be used as a reminder (Notoatmodjo, 2010).

\section{The effect of community-based health education on attitudes of Covid-19 prevention}

Based on the results of the study, it was found that the difference in attitude scores in the control group and the intervention group showed that community-based health education treatment were effective in improving attitudes to prevent Covid-19. The results of this study are in line with research conducted by Syarif et al. (2015) that health education using audio visual media can increase knowledge and behavior of clean and healthy lifestyle patterns in preventing TB transmission (Hartiningsih, 2018). Based on the research results, health education can improve the attitude of the intervention group. Attitudes clearly show reactions to the suitability of stimuli in everyday life, attitudes are the willingness to act and not the implementation of actions, the higher the knowledge, the better attitude will be formed (Azwar, 2013).

According to the Knowledge-Attitude-Behavior Model theory, knowledge is an essential factor that can influence behavior change, and individuals can acquire knowledge and skills through the learning process (Liu et al, 2016). Health promotion is basically a process of communication and a process of behavior change through health education. Health promotion activities can achieve maximum results if the methods and media get great attention and must be adjusted according to the target. The use of a combination of various health promotion methods and media will greatly assist in the process of delivering health information to the public (Suprayitno, Purnomo, et al., 2020). According to Bloom's theory, individual or group after being given health education can improve 3 domains, namely cognitive, affective, and psychomotor so that their knowledge and attitudes will increase. Individual or group after being given health education will go through the process of remembering the material that has been studied, then the individual will understand (comprehension), namely the ability to explain and interpret correctly, then exercise the material that has been studied, and analyze the results of the actions (Notoatmodjo, 2010). The results of the study are also supported by the education of the respondents, most of whom have high school education, diploma / bachelor degree, where generally someone with higher education will have broader knowledge. If someone with a higher education is given a stimulus on health education, he will react to the stimulus that has been given, so that the attitude is in line with one's health knowledge, according to Daniel Tolossa (2014), a person's low knowledge of TB can affect health knowledge and attitudes. Knowledge and attitudes can be seen how the understanding of the disease about symptoms, causes, ways of prevention. Patients with pulmonary tuberculosis who receive health education will automatically increase their knowledge, so there will be a change in attitude for the better and will be followed by a change in behavior to comply with the treatment program (Azwar, 2013), (Hayati \& Musa, 2016).

According to Bloom's theory, individual or group after being given health education can improve 3 domains, namely cognitive, affective, and psychomotor so that their 


\section{Journal Of Nursing Practice}

http://thejnp.org

ISSN: 2614-3488 (print); 2614-3496 (online)

Vol.5 No.1. October 2021. Page.136-145

knowledge and attitudes will increase. Individual or group after being given health education will go through the process of remembering the material that has been studied, then the individual will understand (comprehension), namely the ability to explain and interpret correctly, then exercise the material that has been studied, and analyze the results of the actions (Notoatmodjo, 2010). Attitude can be considered as a predisposition to respond and act. Predisposing factors for the occurrence of behavior in a person are knowledge and attitudes towards action. Changes in individual knowledge and attitudes begin with the obedience stage, identification will then become internalization. At first, individuals obediently perform the of health workers recommendations or instructions without objection because of sanctions. Then if they gets reward they will obey the recommendations but still temporary, meaning that the action is carried out while there is still supervision. At this point, it is necessary to continue the monitoring so that behavior change is permanent. Changes in individual behavior can be optimal if these changes occur through a process of internalization, where new behaviors are considered positive for individuals which are then integrated with the values of individual's life (Azwar, 2013).

The results of the study are also supported by the education of the respondents, most of whom have high school education and diploma/ bachelor degree, where generally someone with higher education will have broader knowledge. If someone with a higher education is given a stimulus on health education, he will react to the stimulus that has been given, so that the attitude is in line with one's health knowledge, according to Daniel Tolossa (2014), a person's low knowledge of TB can affect health knowledge and attitudes. Knowledge and attitudes can be seen how the understanding of the disease about symptoms, causes, ways of prevention. Patients with pulmonary tuberculosis who receive health education will automatically increase their knowledge, so there will be a change in attitude for the better and will be followed by a change in behavior to comply with the treatment program (Azwar, 2013; Hayati \& Musa, 2016).

The results of this study are in line with the research that health education using audiovisual media can increase knowledge and behavior of hygiene and healthy living habits in preventing TB transmission (Hartiningsih, 2018). The results of this study are also supported by the level of education in the control group 1, most of them have a minimum of senior high education, where one of the factors affecting knowledge and attitudes is the level of education. A higher level of education will increase a person's ability to understand faster than those with less education. The higher the level of education, the easier it is for the person to receive information (Hayati \& Musa, 2016). According to Hesti's research (2016), the higher the level of education, insight and knowledge will also be broader, including the knowledge of sufferers and their families (Hayati \& Musa, 2016)

\section{CONCLUSION}

Based on the results of the research and discussion previously described, community-based health education affects the knowledge and attitudes of the community in preventing Covid-19 through the habit of hand-washing with soap and wearing a mask. It is hoped that the public will take steps to prevent the transmission of covid-19 by complying with health protocols, namely by wearing masks and hand-washing regularly with soap.

\section{ACKNOWLEDGMENTS}

The authors would like to thank the participants of this study

\section{CONFLICTS OF INTEREST}

There is no conflict of interest 


\section{Journal Of Nursing Practice}

http://thejnp.org

ISSN: 2614-3488 (print); 2614-3496 (online)

Vol.5 No.1. October 2021. Page.136-145

\section{REFERENCES}

Alahdal, H., Basingab, F., \& Alotaibi, R. (2020). An analytical study on the awareness, attitude and practice during the COVID-19 pandemic in Riyadh, Saudi Arabia. Journal of Infection and Public Health, 2. https://doi.org/https://doi.org/10.1016/j.jiph.2020.06.015

Ali, I., \& Alharbi, O. M. L. (2020). COVID-19: Disease, management, treatment, and social impact. Science of the Total Environment, 138861.

Azwar, S. (2013). Sikap Manusia: Teori dan Pengukurannya. In Sikap Manusia: Teori dan Pengukurannya. https://doi.org/10.1038/cddis.2011.1

Cucinotta, D., \& Vanelli, M. (2020). WHO declares COVID-19 a pandemic. Acta BioMedica: Atenei Parmensis, 91(1), 157-160.

Daryanto, T. R. (2015). Teori Belajar dan Proses Pembelajaran yang Mendidik. Penerbit Gava Media: Yogyakarta.

Eikenberry, S. E., Mancuso, M., Iboi, E., Phan, T., Eikenberry, K., Kuang, Y., Kostelich, E., $\&$ Gumel, A. B. (2020). To mask or not to mask: Modeling the potential for face mask use by the general public to curtail the COVID-19 pandemic. Infectious Disease Modelling.

Hartiningsih, S. N. (2018). Pengaruh pendidikan kesehatan dengan media audiovisual dan media booklet terhadap perilaku caregiver dalam mencegah tuberkulosis pada anggota keluarga. Health Sciences and Pharmacy Journal, 2(3), 97-102.

Hayati, D., \& Musa, E. (2016). Hubungan Kinerja Pengawas Menelan Obat Dengan Kesembuhan Tuberkulosis Di UPT Puskesmas Arcamanik Kota Bandung. Jurnal Keperawatan BSI, 4(1).

Huang, C., Wang, Y., Li, X., Ren, L., Zhao, J., Hu, Y., Zhang, L., Fan, G., Xu, J., \& Gu, X. (2020). Clinical features of patients infected with 2019 novel coronavirus in Wuhan, China. The Lancet, 395(10223), 497-506.

Huriah, T. (2007). Efektifitas Model Community As Partner dalam Memberikan Asuhan Keperawatan Komunitas pada Kelompok Balita dengan Gizi Buruk di Kelurahan Pancoran Mas, Kota Depok. Mutiara Medika, 7(2), 88-96.

Jaimes, J. A., Millet, J. K., Stout, A. E., André, N. M., \& Whittaker, G. R. (2020). A tale of two viruses: the distinct spike glycoproteins of feline coronaviruses. Viruses, 12(1), 83.

Jaji, J. (2020). PENGARUH PENDIDIKAN KESEHATAN DENGAN MEDIA LEAFLETTERHADAP PENGETAHUAN WARGA DALAM PENCEGAHAN PENULARAN COVID 19. Proceeding Seminar Nasional Keperawatan, 6(1), 135140.

Jin, Y.-H., Cai, L., Cheng, Z.-S., Cheng, H., Deng, T., Fan, Y.-P., Fang, C., Huang, D., Huang, L.-Q., \& Huang, Q. (2020). A rapid advice guideline for the diagnosis and treatment of 2019 novel coronavirus (2019-nCoV) infected pneumonia (standard version). Military Medical Research, 7(1), 4.

Lotfi, M., Hamblin, M. R., \& Rezaei, N. (2020). COVID-19: Transmission, prevention, and potential therapeutic opportunities. Clinica Chimica Acta, 508(May), 254-266. https://doi.org/10.1016/j.cca.2020.05.044

MUNIR, M. (2015). PENGEMBANGAN PONKESDES MENJADI COMMUNITY NURSING CENTER BERBASIS HEALTH PROMOTION MODEL, NURSING CENTER, DAN PERILAKU KINERJA DI KABUPATEN TUBAN. UNIVERSITAS AIRLANGGA.

Notoatmodjo, S. (2010). Ilmu Perilaku Kesehatan, Penerbit Rineka Cipta. Jakarta.

Pradhan, D., Biswasroy, P., Ghosh, G., \& Rath, G. (2020). A review of current interventions for COVID-19 prevention. Archives of Medical Research. 


\section{Journal Of Nursing Practice}

Sakti. (2020). Satu pasien positif covid-19 di pamekasan meninggal jadi kasus pertama di madura. https://madura.tribunnews.com/2020/03/30/satu-pasien-positif-covid-19-dipamekasan-meninggal-jadi-kasus-pertama-di-madura

Sohrabi, C., Alsafi, Z., O’Neill, N., Khan, M., Kerwan, A., Al-Jabir, A., Iosifidis, C., \& Agha, R. (2020). World Health Organization declares global emergency: A review of the 2019 novel coronavirus (COVID-19). International Journal of Surgery, 76(February), 71-76. https://doi.org/10.1016/j.ijsu.2020.02.034

Suprayitno, E., Purnomo, J. D. T., Sutikno, S., \& Indriyani, R. (2020). Health education in principle of community affected teenagaer's smooking attitude and habitual in the coastal area of madura island indonesia. International Journal of Psychosocial Rehabilitation, 24(10), 1492-1502. https://doi.org/10.37200/IJPR/V24I10/PR300173

Suprayitno, E., Rahmawati, S., Ragayasa, A., \& Pratama, M. Y. (2020). Pengetahuan dan Sikap Masyarakat dalam Pencegahan COVID-19. Journal Of Health Science (Jurnal Ilmu Kesehatan), 5(2), 68-73.

Surgery, N., Ren, J., Yang, X., Xu, Z., Lei, W., Yang, K., Kong, Y., Qu, J., He, Y., Chen, H., Wang, Y., Zeng, F., Hua, Q., Surgery, N., \& Surgery, N. (2020). Prevention of nosocomial COVID-19 infections in Otorhinolaryngology-Head and Neck Surgery. https://doi.org/10.1016/j.wjorl.2020.06.003

Ulya, Z., Iskandar, A., \& Triasih, F. (2018). Pengaruh Pendidikan Kesehatan dengan Media Poster terhadap Pengetahuan Manajemen Hipertensi pada Penderita Hipertensi. Jurnal Keperawatan Soedirman, 12(1), 38-46.

Zeinomar, N., \& Moslehi, R. (2013). The effectiveness of a community-based breast cancer education intervention in the New York State Capital Region. Journal of Cancer Education, 28(3), 466-473. 